\title{
In vitro assembly of yeast U6 snRNP: a functional assay
}

\author{
Patrizia Fabrizio, David S. McPheeters, and John Abelson ${ }^{1}$ \\ Division of Biology 147-75, California Institute of Technology, Pasadena, California 91125 USA
}

\begin{abstract}
U6 small nuclear RNA (snRNA) is the most highly conserved spliceosomal RNA, and it has been postulated to have a fundamental role in pre-mRNA splicing. To elucidate this role, we developed an in vitro system for reconstituting the functional U6 small ribonucleoprotein (snRNP). Treating splicing extracts with an oligonucleotide complementary to the central domain of U6 snRNA leads to both RNase $H$ cleavage of the endogenous U6 snRNA and loss of splicing activity. Yeast U6 RNA, synthesized in vitro using T7 RNA polymerase, is then added to the oligonucleotide-treated extract, and restoration of splicing activity is monitored by the subsequent addition of substrate pre-mRNA. Addition of full-length, unmodified T7U6 snRNA (113 nucleotides) to oligonucleotide-treated extracts restores splicing activity efficiently. Using U6 RNA transcripts truncated at their $3^{\prime}$ ends, we show that large deletions ( 39 nucleotides) produce molecules that are unable to restore splicing activity in vitro and cannot interact with the endogenous U4 snRNA or form a mature spliceosome. Finally, we show that substitution of the invariant G81 with C within the T7U6 RNA abolishes its ability of restoring splicing activity. Although the U4/U6 snRNP forms correctly, mature spliceosomes do not assemble.
\end{abstract}

[Key Words: Functional assay; splicing; U6 snRNA]

Received August 24, 1989; revised version accepted October 13, 1989.

Splicing of nuclear mRNA and group II mitochondrial RNAs follows a common two-step mechanism of cleavage-ligation reaction (for review, see Green 1986; Padgett et al. 1986). Because splicing of group II mitochondrial RNAs can proceed by itself in the absence of any cofactor, catalysis must be achieved by the formation of active sites comprised solely of RNA (Peebles et al. 1986; Van der Veen et al. 1986). In contrast, splicing of nuclear mRNA requires numerous RNAs, proteins, and complex protein-RNA interactions. At least five small nuclear RNAs (snRNAs), U1, U2, U5, U4, and U6, are required for nuclear mRNA splicing in eukaryotes. These RNAs are associated with protein and function in the form of ribonucleoprotein complexes (snRNPs) (Krämer et al. 1984; Black et al. 1985; Chabot et al. 1985; Krainer and Maniatis 1985; Berget and Robberson 1986; Black and Steitz 1986; for review, see Reddy and Busch 1988; Lührmann 1988). Splicing involves interaction of the pre-mRNA with snRNPs and many cellular factors (for review, see Sharp 1987; Maniatis and Reed 1987; Vijayraghavan and Abelson 1989) to form a large complex termed the spliceosome (Brody and Abelson 1985; Frendewey and Keller 1985; Grabowski et al. 1985). Some of the snRNPs interact directly with the pre-mRNA (Chabot and Steitz 1987; Steitz et al. 1988). The U1 snRNP is the first to bind, and it interacts with the $5^{\prime}$ splice site and the branchpoint (Mount et al. 1983; Zhuang and Weiner 1986; Ruby and Abelson 1988). The U2 snRNP binds to the branchpoint (Parker et al. 1987),

${ }^{1}$ Corresponding author. and the U5 snRNP possibly binds to the $3^{\prime}$ splice site (Gerke and Steitz 1986; Tazi et al. 1986). The U4 and U6 snRNAs are associated together in the same snRNP (Bringman et al. 1984; Hashimoto and Steitz 1984). Although the U4/U6 snRNP is required for splicing (Berget and Robberson 1986; Black and Steitz 1986), there is no evidence that it interacts directly with the precursor.

Splice site selection in nuclear pre-mRNA is dictated by short sequences at or near the splice junctions (Shapiro and Senapathy 1987). U-snRNPs have been proposed to be involved in properly aligning splice junctions in pre-mRNAs to confer the appropriate architecture for catalysis (Lerner et al. 1980; Rogers and Wall 1980 |, similar to that specified by the self-splicing type I and II intron sequences (see Cech 1986). Alternatively, the snRNP components of the spliceosome may be directly responsible for catalysis of the intron excision and/or exon ligation reactions, although no catalytic activities of snRNPs have been identified thus far.

The U6 snRNA is the most highly conserved spliceosomal snRNA (Das et al. 1987; Brow and Guthrie 1988); U6 snRNAs from rat, yeast, and plant are $>70 \%$ homologous. The apparent constraints on both the size and the sequence of U6 argues for a central role in the splicing process (Guthrie and Patterson 1988). On the basis of conserved structural features, the U6 sequence has been divided into four domains (Brow and Guthrie 1988). The 5 '-terminal domain (nucleotides 1-27) contains a hairpin structure highly variable in length among species, which is responsible for essentially all the differences in size of the U6 RNAs. The central domain 
(nucleotides 28-54) seems likely to be single-stranded, because of its RNase $\mathrm{H}$ susceptibility (Guthrie and Patterson 1988). The contiguous stretch of conserved sequences (nucleotides 55-80) in U6 has been proposed to base-pair with U4 to form two contiguous stems that lie within the most highly conserved segment of U6 (Bringmann et al. 1984; Hashimoto and Steitz 1984; Rinke et al. 1985; Das et al. 1987; Siliciano et al. 1987; Kiss et al. 1988; Zucker-Aprison et al. 1988; Mottram et al. 1989). Finally, the $3^{\prime}$-terminal domain is divergent in sequence but constant in length (nucleotides $81-112$ ). It has been proposed that the association between $\mathrm{U} 4$ and $\mathrm{U} 6$ is a dynamic one and that stable U4/U6 interaction is disrupted during splicing in vitro /Cheng and Abelson 1987; Lamond et al. 1988). Interestingly, U6 sequences bound by $\mathrm{U} 4$ show markedly higher conservation than does the comparable region of $\mathrm{U} 4$, suggesting that this region of U6 may be involved in catalysis (Brow and Guthrie 1989). This hypothesis is supported by the discovery of an intron within the single-copy gene encoding U6 RNA in the fission yeast Schizosaccharomyces pombe, which is located precisely in the middle of the most highly conserved region of U6 (Tani and Ohshima 1989). The site of intron insertion may reflect the proximity of that part of $\mathrm{U} 6$ to the catalytic center of the spliceosome.

Assembly of the snRNAs with proteins to form snRNP particles has been studied in vivo and in vitro using immunological methods and has provided extensive data of their structure (for review, see Mattaj 1988, 1989; Parry et al. 1989). However, the current lack of functional assays for in vitro-assembled U-snRNPs complicates further progress. A functional analysis is a powerful ally of the structural studies to understand the complexities of the assembly process. By synthesizing U6 snRNA in vitro with T7 RNA polymerase and combining it with Saccharomyces cerevisiae extracts depleted of their endogenous U6 RNA, we have been able to assemble the synthetic transcript into a functional snRNP able to reconstitute $50-100 \%$ of splicing activity in vitro. The reconstituted U6 snRNP comigrates with the endogenous U6 snRNP on nondenaturing polyacrylamide gels, it is immunoprecipitated by the same antibodies and it participates in spliceosome formation. Thus, the newly formed particle is structurally identical to the endogenous U6 snRNP. Until now, only in vivo approaches have been used to determine the effects of snRNA mutations on splicing (Parker et al. 1987; Seraphin et al. 1988; Siliciano and Guthrie 1988), but no in vitro systems have been available for studying the function of U6 RNA mutations and analyzing the functions of U6 snRNP in splicing. The assay offers the advantage of flexibility and ease of manipulation for the study of the pre-mRNA splicing mechanism.

\section{Results}

U6 snRNA can be specifically degraded in yeast extract

To test whether the synthetic U6 RNA could assemble into a functional snRNP, we first had to inactivate the endogenous yeast U6 snRNP. We tested the ability of the oligonucleotides $b$, d, and $f$ (Fig. 1A), which are complementary to nucleotides $1-32,33-81$, and $82-112$, respectively, in U6 snRNA, to direct RNase $\mathrm{H}$ cleavage of the target RNA in a yeast splicing extract. These oligonucleotides were also used to construct the synthetic U6 RNA gene (see Materials and methods).

Oligonucleotides $\mathrm{b}, \mathrm{d}$, and $\mathrm{f}$, as well as the control oligonucleotide $\mathrm{c}$ (Fig. 1A), were incubated in yeast splicing extract for $30 \mathrm{~min}$ at $30^{\circ} \mathrm{C}$. Then, RNA was analyzed by Northern blot, using labeled U6 and U4 oligonucleotides as probes. Figure 2A (lane 2) shows that the control oligonucleotide $\mathrm{c}$ has no effect. The effects of oligonucleotides $b, d$, and $f$ are shown, respectively, in the presence and absence of ATP. Only oligonucleotide $d$ caused complete cleavage of the U6 RNA in the extract (lanes 5 and 6), and this degradation was strongly ATP dependent (cf. lanes 5 and 6 with lanes 15 and 16). About $60 \%$ of the U6 RNA was truncated when incubated with $3 \mu \mathrm{M}$ oligonucleotide $\mathrm{b}$, either in the presence (lane 3) or absence of ATP (lane 13). Oligonucleotide $\mathrm{f}$, complementary to the $3^{\prime}$-terminal domain, caused almost $100 \%$ cleavage of the U6 RNA at $3 \mu \mathrm{M}$, either in the presence or absence of ATP. Oligonucleotide $d$ is complementary to both the central domain and the U4/U6 interaction domain. To determine whether the efficient cleavage produced by oligonucleotide $d$ resulted exclusively from its complementarity to the central domain, we tested two shorter oligonucleotides: $\mathrm{d} 1$, which is complementary to nucleotides 28-54 of the central domain (Fig. $1 \mathrm{~B} \mid$, and $\mathrm{d} 2$, which is complementary to nucleotides $55-80$ of the U4/U6 interaction domain. Only oligonucleotide d1 (at $0.3 \mu \mathrm{M}$ ) completely cleaved its target RNA, and the cleavage was strictly ATP dependent (Fig. $2 \mathrm{~A}$, cf. lane 10 with lane 20 . The same effect has been observed previously with an oligonucleotide complementary to residues $43-60$ of the HeLa U6 RNA. On binding ATP, the U6 particle may undergo a conformational change, exposing sequences that become accessible to RNase H cleavage (Black and Steitz 1986).

\section{Cleavage of U6 RNA inhibits splicing in vitro}

To test whether the cleavage of yeast U6 RNA inhibited splicing activity, the extract was incubated under splicing conditions, first with an oligonucleotide and then with pre-mRNA substrate. The extract preincubated without an oligonucleotide (Fig. 2B, lane 1) shows the expected reaction products and intermediates. Preincubation with $\mathrm{c}, \mathrm{b}$, or $\mathrm{d} 2$ oligonucleotides allowed similar quantities of spliced pre-mRNA to be produced. A reduced formation of spliced message, together with a slight accumulation of excised intron, could be seen in the samples treated with $3 \mu \mathrm{M}$ oligonucleotide $\mathrm{f}$ (lanes 7 and 17). In contrast, pretreatment with either $\mathrm{d}$ or $\mathrm{dl}$ oligonucleotides resulted in the complete disappearance of spliced actin pre-mRNA (lanes 5 and 6; 9 and 10). When the preincubation was done in the absence of ATP (lanes 13-20), only oligonucleotides $\mathrm{d}$ and $\mathrm{d} 1$ prevented the appearance of both splicing intermediates and 


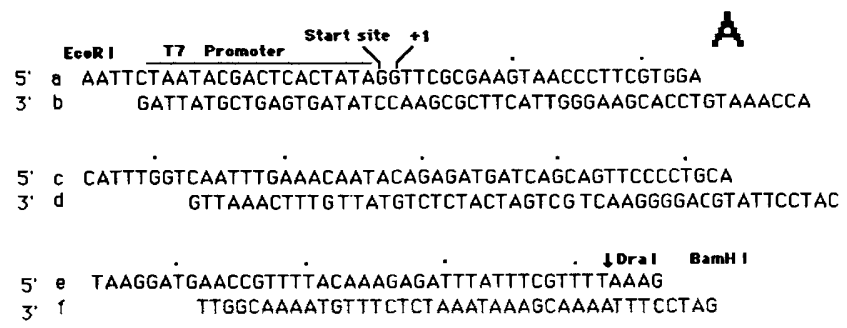

$U_{6}$
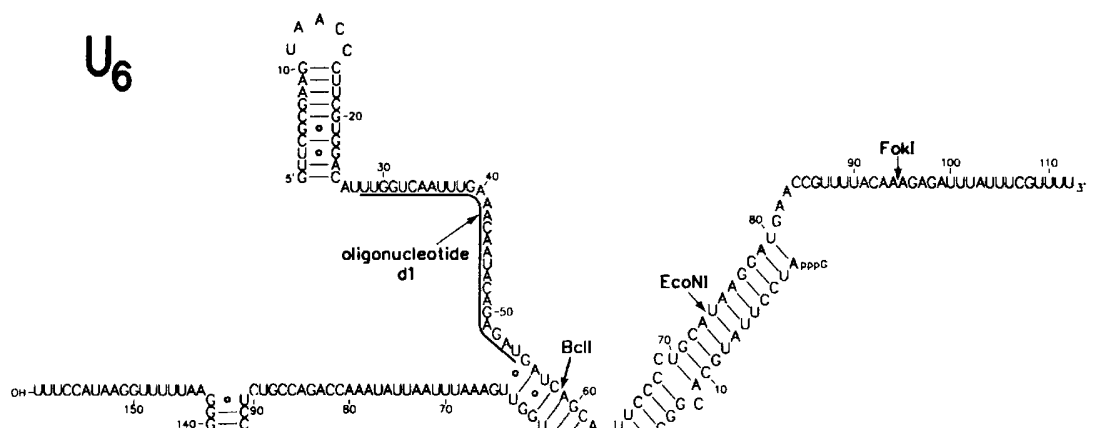
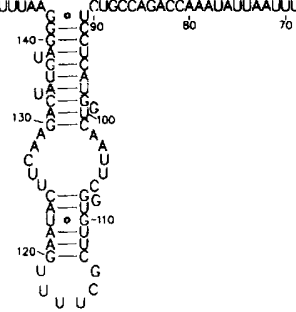

${ }_{60}^{\circ} C_{G}$

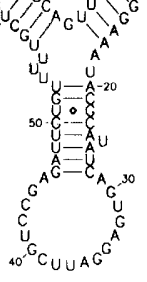

$\bigcup_{4}$

products but only at the highest concentration used 3.0 $\mu \mathrm{M}$, lanes 15 and 19). At the low amount of both oligonucleotides, splicing of the precursor was not inhibited (lanes 16 and 20). Because ATP was added during the splicing phase of the incubation, it appears that the oligonucleotides, themselves, were degraded during the preincubation.

\section{Stability of oligonucleotides incubated in yeast extract}

To prevent cleavage of the T7U6 RNA after its addition to the treated extract, it was important to determine that the oligonucleotides were degraded themselves during the incubation in yeast extract. The stability of oligonucleotide $\mathrm{d}$ was analyzed by incubating the 3 '-terminal-labeled oligonucleotide in yeast extract under splicing conditions (Fig. 3, lanes 3 and 4). Within $30 \mathrm{~min}$, $<1 \%$ of intact oligonucleotide was detected (lane 4, 0.3 $\mu \mathrm{M}$ oligonucleotide). Very high quantities of oligonucleotides, up to $3.0 \mu \mathrm{M}$, were not completely degraded during the incubation time of $30 \mathrm{~min}$ at $30^{\circ} \mathrm{C}$ (data not shown). We found that the concentration of oligonucleotides $\mathrm{d}$ or $\mathrm{d} 1 \mathrm{necessary}$ and sufficient to induce complete cleavage of U6 snRNA varied among different extracts from 0.15 to $0.3 \mu \mathrm{M}$ (data not shown).

\section{In vitro-synthesized U6 RNA restores splicing activity}

We asked whether the synthetic U6 RNA was able to assemble into a snRNP when incubated in the yeast ex-
Figure 1. (A) Oligonucleotides for $T 7$ promoter/U6 snRNA gene construction. The six oligonucleotides-a (47 nucleotides), b 151 nucleotides), c (49 nucleotides), d (49 nucleotides), e (43 nucleotides), and f (39 nucleotides)-are shown as base-paired duplexes. The construct was cloned into the EcoRI/ BamHI sites of Ml3mpl8 and subcloned into pUC18, as described in Materials and methods. (Start site) Start of the transcription. $(+1)$ The first nucleotide in the snRNA U6 gene. The T7 promoter is overlined. The DraI termination site is shown upstream from the BamHI terminus. (B) Proposed secondary structure of the yeast U4/U6 snRNAs (Brow and Guthrie 1988; Guthrie and Paterson 1988). The sequence complementary to oligonucleotide $\mathrm{d} 1$ is underlined. Arrows indicate the $3^{\prime}$ ends of the various runoff transcripts described in the text. tract depleted of its endogenous counterpart and whether the newly generated particle was capable of mediating pre-mRNA splicing. Figure 4 shows a titration curve of unlabeled U6 RNA synthesized in vitro using T7 RNA polymerase added to the depleted extract at various concentrations (from 200 to $0.05 \mathrm{nM}$ ). After 7 min of preincubation at $23^{\circ} \mathrm{C}$, splicing activity was assayed by the addition of labeled pre-mRNA splicing substrate $(0.2 \mathrm{nM})$. Samples that had received in vitro-synthesized U6 RNA produced actin RNA that was efficiently spliced (lanes 3-12). Extracts that had been treated with oligonucleotide $\mathrm{d} 1$ and then with tRNA or in vitro-synthesized U4 RNA before being incubated with the substrate were found to contain only unspliced pre-mRNA (data not shown). Routinely, addition of 10 nM T7U6 RNA to oligonucleotide-treated extracts reconstitutes $50-100 \%$ of splicing activity of control extracts. This concentration is similar to the level of the endogenous U6 snRNA present in the extract; our standard splicing assay contains 4-8 nM endogenous U6 RNA (data not shown). Thus, the synthetic U6 RNA can restore splicing activity in vitro when present at similar levels to that of the endogenous U6 snRNA.

\section{Formation of snRNPs with synthetic U6 RNA}

We used immunoprecipitation experiments and nondenaturing gel analysis to determine whether the in vitro assembled U6 snRNP was not only functionally active but also structurally correct. After incubating the syn- 

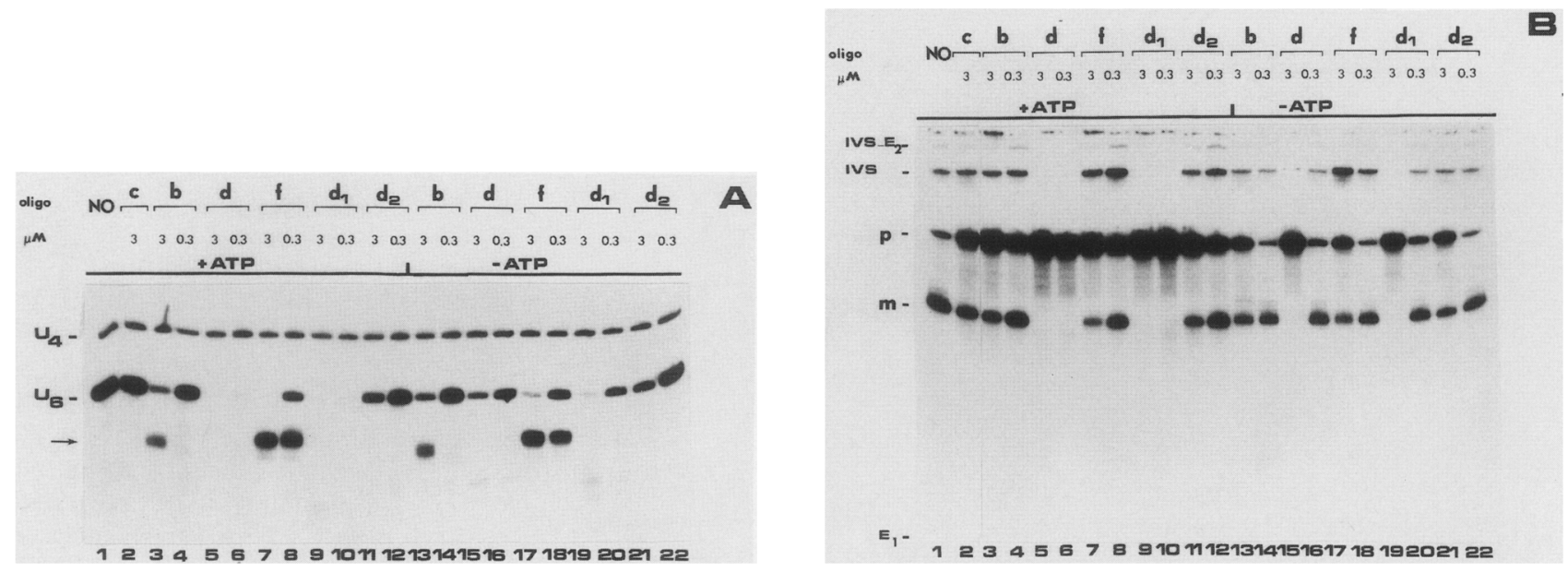

Figure 2. RNase $\mathrm{H}$ cleavage of U6 snRNA in yeast extract. Various oligonucleotides $\left(0.3\right.$ or $3.0 \mu M_{;}$listed in Fig. $\left.1 \mathrm{~A}, \mathrm{~B}\right)$ were incubated with yeast extract in the presence or absence of exogenous ATP for $30 \mathrm{~min}$ at $30^{\circ} \mathrm{C}$. (A) Digestion of U6 snRNA was monitored by Northern hybridization using labeled U6 and U4 probes. (Lane 1) No oligonucleotide was added. The lowest bands (arrow) are specific cleavage products of U6 RNA. $(B)$ Splicing of the actin pre-mRNA substrate in oligonucleotide-treated extracts. After treatment of the extract with various oligonucleotides in the presence or absence of ATP, ATP was added at 2 mM (lanes 13-22), and a standard mRNA splicing reaction was carried out using actin pre-mRNA as substrate. The major reaction products and intermediates are labeled as follows: (IVS- $\left.E_{2}\right)$ Intron-exon 2; (IVS) the excised intron; $(p)$ precursor $R_{N A}(m)$ the spliced message; $\left(E_{1}\right)$ the excised exon 1 .

thetic U6 RNA in the depleted extract, the assembly mix was immunoprecipitated with anti- $\mathrm{m}_{3} \mathrm{G}$ or antiPRP4 antibodies. It was shown previously that anti- $\mathrm{m}_{3} \mathrm{G}$ antibodies could immunoprecipitate $\mathrm{U} 4$ as a consequence of its trimethylguanosine cap structure at its $5^{\prime}$ end (Bringmann et al. 1983). The endogenous U6 does not have a trimethylguanosine cap structure but can be immunoprecipitated by anti- $m_{3} G$ antibodies because of its association with U4 (Bringman et al. 1984). It has also been shown (Banroques and Abelson 1989) that the $52-\mathrm{kD}$ protein encoded by the PRP4 gene of $S$. cerevisiae is a U4/U6 snRNP protein. The RNA species immunoprecipitated (Fig. 5A) were quantitated by Northern blot analysis using labeled $\mathrm{U} 4$ and $\mathrm{U} 6$ oligonucleotides as probes. As expected, both antibodies immunoprecipitated the U4/U6 snRNP (lanes 1 and 2). When the extract was treated with oligonucleotide $\mathrm{dl}$, U6 was no longer immmunoprecipitated (lanes 3 and 4). When synthetic U6 RNA was added to inactivated extracts, U6 was again immunoprecipitated. Synthetic U6 RNA efficiently associates with the endogenous $\mathrm{U} 4$ and it forms a structurally correct snRNP, which is immunoprecipitated by both antibodies (lanes 6-11). No immunoprecipitation could be detected with the pre-immune serum (lane 5).

In vitro-reconstituted U6 snRNPs were also analyzed by electrophoresis in a nondenaturing gel (in the absence of added precursor mRNA). Northern analysis was performed using $\mathrm{U} 6$ or $\mathrm{U} 4$ oligonucleotide as probes. Hybridization with the $\mathrm{U} 6$ probe revealed the position of the endogenous U6 snRNP in control extracts (Fig. 5B, lane 1). In whole-cell extract, the U6 snRNP exists in three complexes, termed III', III, and V (Cheng and Abelson 1987). In our analysis, the majority of U6 was found in complex $\mathrm{V}$, whereas the rest of it was detected in the slower migrating complexes III and III', which also contained U4. Complex V probably represents the free U6 snRNP (at least free of U4), because there was no detectable U4 in this band. After treatment with oligonucleotide $\mathrm{d} l$, the endogenous U6 snRNPs were destroyed, because U6 RNA was no longer detected in the blot. U4 could be seen in the same sample, but its mobility changed after the cleavage of U6 (lane 2, U4 probe). The complexes detected represent two new forms of U4.

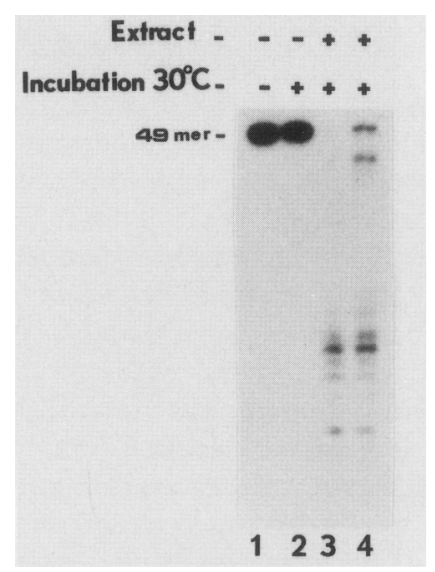

Figure 3. Stability of oligonucleotides incubated in yeast extract. Oligonucleotide $d$ (49-mer) was $3^{\prime}$-terminal labeled with $5^{\prime}-[32 \mathrm{P}] \mathrm{pCP}$ and incubated for $30 \mathrm{~min}$ at $30^{\circ} \mathrm{C}$ in the presence (lanes 3 and 4) or absence (lane 2) of extract. Either $0.15 \mu \mathrm{M}$ (lanes $1-3$ ) or $0.3 \mu \mathrm{M}$ (lane 4) oligonucleotide was used. After deproteinization, the oligonucleotide was analyzed on a $15 \%$ acrylamide $-8 \mathrm{~m}$ urea gel. 


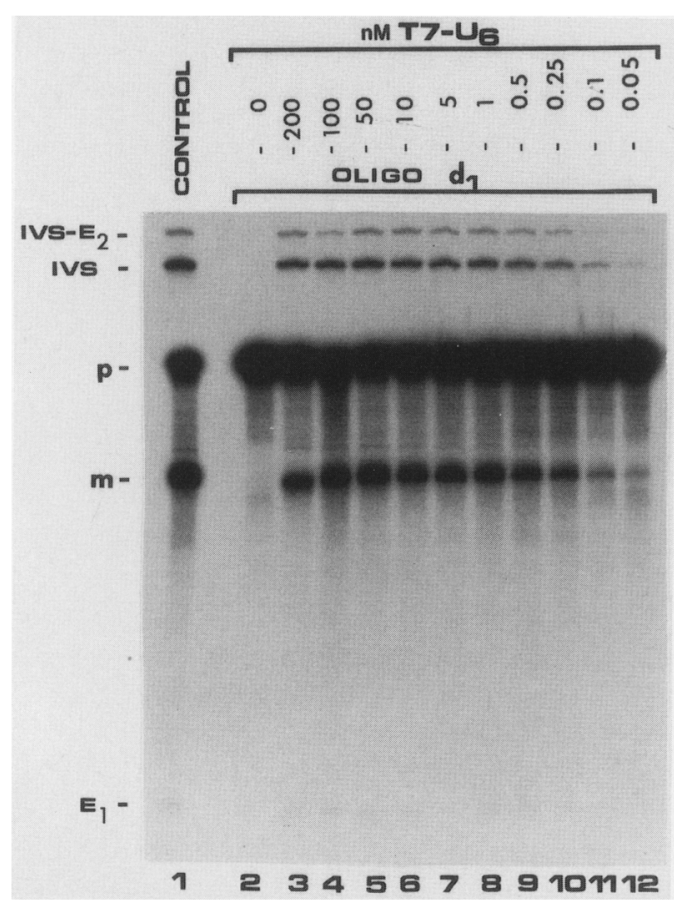

Figure 4. In vitro-synthesized U6 RNA restores splicing activity. The yeast extract was not treated (lane 1) or treated for $30 \mathrm{~min}$ at $30^{\circ} \mathrm{C}$ with $0.3 \mu \mathrm{M}$ oligonucleotide $\mathrm{d} 1$ in the presence of 2 mM ATP (lanes 2-12). Various concentrations of unlabeled T7U6 transcript were added (lanes 3-12), and incubation was continued for $7 \mathrm{~min}$ at $23^{\circ} \mathrm{C}$. A standard mRNA splicing reaction was carried out using ${ }^{32} \mathrm{P}$-labeled actin pre-mRNA as substrate. RNAs were analyzed on an $8 \%$ acrylamide $-8 \mathrm{M}$ urea gel. The major reaction products and intermediates are labeled as follows: (IVS- $E_{2}$ ) Intron-exon 2; (IVS) the excised intron; (p) precursor RNA; $(\mathrm{m})$ the spliced message; $\left(\mathrm{E}_{1}\right)$ the excised exon 1.

Note that it seems unlikely that the band comigrating with complex III represents complex III, because it does not hybridize with the U6 probe. When the synthetic U6 RNA was incubated in the depleted extract, we observed the formation of two complexes with mobilities identical to those of forms V and III. When U6 RNA was added at a concentration of $10 \mathrm{~nm}$ (lane 3), only a part of it was assembled into forms V and III, whereas the rest of the U6 RNA was present as a fast migrating smear, which may represent naked U6 RNA. At a lower concentration (1 $\mathrm{nM})$, the transcript was completely incorporated into complex III instead (lane 4). This experiment shows that the T7U6 RNA assembles in an snRNP that has the same electrophoretic mobility of the endogenous U6 snRNP on nondenaturing gels.

\section{Spliceosome formation in reconstituted extracts}

It has been shown (Pikielny et al. 1986; Cheng and Abelson 1987) that at least four splicing-specific complexes can be resolved by electrophoresis on nondenaturing polyacrylamide gels after the assembly of the yeast spliceosome. Complex B, the first detectable intermediate to form (Cheng and Abelson 1987), contains both pre-mRNA and the U2 snRNP. A large complex then forms (complex A2), which contains U4/U6 and U5 particles in addition. Subsequently, U4 leaves the complex (complex A1), and a mature spliceosome is obtained that contains pre-mRNA, intermediates, products, and U2, U5, and U6 snRNPs. In Figure 6A (lanes 4-6), the extract was preincubated with oligonucleotide $\mathrm{dl}$, and after the addition of ${ }^{32} \mathrm{P}$-labeled pre-mRNA, the complexes were electrophoretically separated on a nondenaturing gel. We observed that only complex B accumulated. An intact U6 snRNP is required for further assembly of the spliceosome. When ${ }^{32} \mathrm{P}$-labeled, full-length U6 snRNA and then unlabeled actin pre-mRNA were added to the depleted extract (Fig. 6B, lanes 5 and 6), we observed the formation of two complexes with mobilities identical to that of $\mathrm{A} 1$ and $\mathrm{A} 2$ complexes. No complexes could be detected in the absence of premRNA (lane 4). The controls (Fig. 6A, B, lanes 1-3) consisted of a standard splicing reaction in which the extract was preincubated with no oligonucleotide and the precursor was labeled with ${ }^{32} \mathrm{P}$. Figure $6 \mathrm{~B}$, (lanes $7-12$ ) shows spliceosome formation after reconstitution with U6 RNA transcripts truncated at their $3^{\prime}$ ends. These were obtained by digesting the pT7U6 DNA template with FokI (causing it to lack 18 nucleotides of the $3^{\prime}$-terminal domain), with EcoNI [causing it to lack the 3'-terminal domain ( 32 nucleotides) and 7 nucleotides of the U4/U6 interaction domain], and with BclI [causing it to lack the 3 '-terminal domain and the majority of the U4/U6 interaction domain (22 nucleotides); see Fig. 7A and 1B respectively. The FokI/U6 transcript was incorporated into the same complexes as the full-length U6 RNA (although the complexes formed appeared to be less stable to gel electrophoresis|. In contrast, the EcoNI and the BclI truncated transcripts were not found in either complex, suggesting that the deleted region(s) was required for the formation of complexes involved in splicing.

Identification of U6 sequences required for pre-mRNA splicing in vitro

We used the in vitro $\mathrm{U} 6$ reconstitution system to identify sequences within the U6 snRNA that are required for snRNP assembly and pre-mRNA splicing. In our first approach, we compared the splicing efficiency restored by several U6 RNA transcripts that were shorter or longer than the reference U6 molecule (113 nucleotides; Fig. 7A). The BamHI/U6 RNA containing eight extra nucleotides at the $3^{\prime}$ end (Fig. 7B, lanes 6-8) gave a lower reconstitution of splicing activity. The FokI/U6 RNA also was incapable of complete recovery of splicing (lanes 9-11). Interestingly, with this transcript, the intron lariat accumulated slightly and there was a decrease in the level of the spliced mRNA (at $10 \mathrm{nM}$; lane 9). When the U6 molecule was shortened further (lanes 12-18), neither splicing intermediates nor products could be detected. To determine whether the inability to restore splicing resulted from the loss of an essential region of U6 or merely to the instability of the shorter 

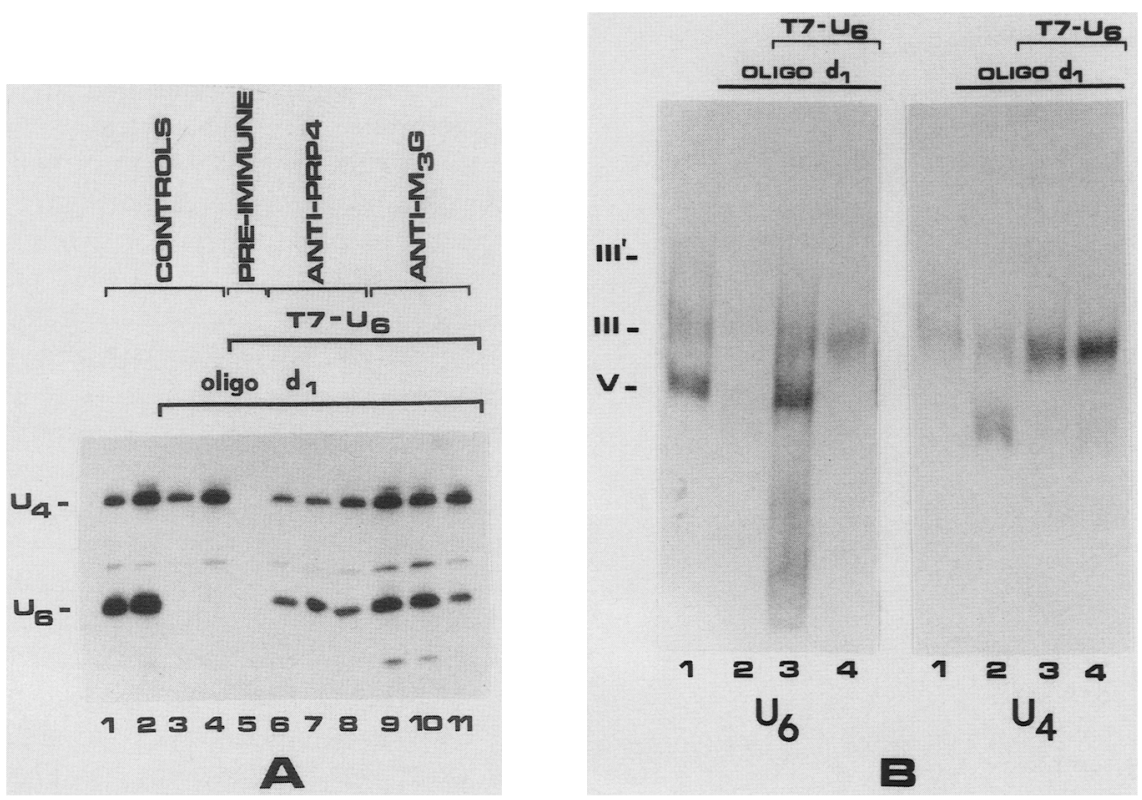

Figure 5. Formation of snRNPs with synthetic U6 RNA. (A) Immunoprecipitation of the synthetic U6 snRNP. The yeast extract was not treated (lanes 1 and 2) or treated with the oligonucleotide for $30 \mathrm{~min}$ at $30^{\circ} \mathrm{C}$ (lanes 3-11). The in vitro-transcribed unlabeled U6 RNA (T7U6) was added at a final concentration of $100 \mathrm{nM}$ (lanes 6 and 9), $10 \mathrm{nM}$ (lanes 5, 7, and 10), or $1 \mathrm{nM}$ (lanes 8 and 11), After incubation at $23^{\circ} \mathrm{C}$, samples were subjected to immunoprecipitation with anti-PRP4 antibodies (lanes 1, 3, 6-8), anti- $\mathrm{m}_{3} \mathrm{G}$ antibodies (lanes 2, 4, 8-11), or preimmune serum (lane 5). RNAs were recovered from immunocomplexes, separated by electrophoresis on a $5 \%$ acrylamide $-8 \mathrm{M}$ urea gel, and analyzed by Northern hybridization with U6 and U4 probes. The bands migrating between U4 and U6 and under $\mathrm{U} 6$ are degradation products of $\mathrm{U} 4$ and $\mathrm{U} 6$, respectively. $(B)$ Analysis of the synthetic U6 snRNP on nondenaturing gel. After treatment of the extract with oligonucleotide dl (lanes 2-4), T7U6 RNA was added and incubated for 7 min at $23^{\circ} \mathrm{C}$ (lanes 3 and 4). No oligonucleotide or T7U6 RNA was added in the control (lane 1). Samples were subjected to electrophoresis on a nondenaturing polyacrylamide gel followed by Northern blot analysis. The same blot was used for hybridization with U6 and U4 probes. The endogenous U6 was present in complexes III', III, and V; the endogenous U4 was present in complexes III' and III. The endogenous U6 was not detected after treatment of the extract with oligonucleotide dl, whereas U4 was found as two new bands. Complex III was reconstituted after addition to the extract of $1 \mathrm{nM}$ T7U6 (lane 4). Both forms III and V could be seen in the samples that received 10 nM T7U6 (lane 3).

transcripts, reconstitution experiments were done using ${ }^{32}$ P-labeled U6 RNA molecules. Figure $7 \mathrm{C}$ shows that all of the transcripts were stable when incubated in the yeast extract. Only the FokI/U6 transcript, after incubation in the extract, was degraded to give a second, shorter band (Fig. 7C, lane 4). These results demonstrate that large deletions of U6 RNA (39 nucleotides or more) produce molecules incapable of reconstituting splicing activity in vitro. The ability of shorter U6 transcripts to interact with the endogenous U4 snRNA was also examined by immunoprecipitation with anti- $\mathrm{m}_{3} \mathrm{G}$ antibodies (Fig. 7D). The FokI/U6 truncated transcript was coprecipitated with the endogenous U4 snRNA to nearly the same extent as the full-length U6 molecule (the shorter degradation product of the FokI/U6 transcript was also coprecipitated; lanes 4 and 5). In contrast, both EcoNI and $B c l$ truncated transcripts were not coprecipitated with the U4 snRNA (lanes 6-9).

\section{Mutational analysis of the $3^{\prime}$-terminal domain of U6 SnRNA}

To understand the importance of the $3^{\prime}$-terminal domain of U6 snRNA in splicing, we analyzed the contribution of conserved nucleotides of this region of the efficiency and fidelity of reconstitution of pre-mRNA splicing in vitro.

We constructed three U6 variants of the $3^{\prime}$-terminal domain: M2C/U6, M2G/U6, and M3/U6, in which invariant nucleotides have been changed, respectively, from position 81 to 95,82 to 95 , and 96 to 108 . The sequence changes in the mutants used in this work are shown in Figure 8A. When M2C/U6 was assayed for its ability to reconstitute splicing activity (Fig. $8 \mathrm{~B}$ ), it was inactive. In contrast, $\mathrm{M} 3 / \mathrm{U} 6$ restored splicing of actin pre-mRNA efficiently. This result confirmed that obtained using the FokI/U6 truncated transcript in reconstitution experiments. The lack of the $3^{\prime}$ half of the $3^{\prime}$ terminal domain of U6 snRNA did not dramatically affect restoration of splicing. Thus, all of the conserved nucleotides of this region can be changed with little effect in efficiency of reconstitution. In contrast, the lack of functionality of M2C/U6 appeared to contradict the finding reached by $\mathrm{RNase} \mathrm{H}$ cleavage experiments. Extracts containing endogenous U6 RNA that was truncated (approximately at nucleotides $82-112$ ) by oligonucleotide f-directed cleavage still spliced pre-mRNA. Thus, the presence of the invariant residue G81 within 


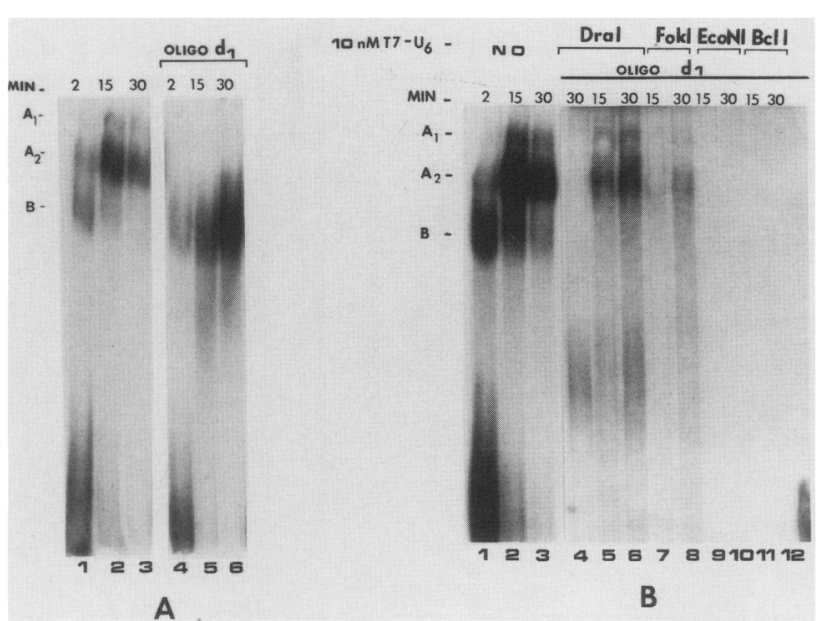

Figure 6. $(A)$ Cleavage of the endogenous U6 blocks the formation of an active spliceosome. The extract was not treated (lanes 1-3) or treated (lanes 4-6) with the oligonucleotide $\mathrm{d} 1$ for $30 \mathrm{~min}$ at $30^{\circ} \mathrm{C}$. Then, samples were incubated 2,15 , and 30 min with ${ }^{32} \mathrm{P}-1$ labeled actin substrate. The complexes were separated by electrophoresis on a nondenaturing polyacrylamide gel. $(B)$ The synthetic U6 snRNP participates in spliceosome formation. Lanes 1-3 are the controls, as in $A$. After treatment with the oligonucleotide, reconstitution was carried out using U6 RNA transcripts of various lengths (see Fig. 7A), labeled with ${ }^{32} \mathrm{P}$ (lanes $4-12$ ). After incubation at $23^{\circ} \mathrm{C}$, unlabeled actin transcript ( $2 \mathrm{nM}$ ) was introduced (lanes 5-12) and incubated for 15 or $30 \mathrm{~min}$ at $23^{\circ} \mathrm{C}$. The precursor was not added in the control (lane 4). The reactions were analyzed as in $A$. The nomenclature of the complexes is that proposed by Cheng and Abelson (1987).

the U6 RNA may be essential for splicing activity. To test this possibility, we constructed M2G/U6, which contains $\mathrm{G}$ instead of $\mathrm{C}$ at position 81 (Fig. 8A). The results of the reconstitution using $\mathrm{M} 2 \mathrm{G} / \mathrm{U} 6 \mathrm{RNA}$ are clear: Splicing is restored, although not at the wild-type level (Fig. 8B). G81 must have an important role in splicing. It probably acts as a contact point with other snRNAs and/or with factors of the spliceosome. Interestingly, M2C/U6 can efficiently base-pair with the endogenous U4, but it does not participate in spliceosome formation (data not shown). This indicates that the interaction of U6 with U4 is not the only element required for further assembly of the spliceosome.

\section{Interesting differences between yeast and human U6}

The primary structure of yeast and human U6 are sufficiently conserved in sequence to be detectable by hybridization with a mouse U6 probe (Siliciano et al. 1987). The yeast U6 (112 nucleotides) is $75 \%$ homologous to human U6 (106 nucleotides) over more than half its length, except for a short variable region at the $5^{\prime}$ terminus that is responsible for all the differences in size of the U6 RNAs (Brow and Guthrie 1988). In light of the recent finding that human U1 and U2 snRNAs are capable of forming functional snRNPs with amphibian proteins (Pan and Prives 1988), it was interesting to know whether the human U6 RNA could recover splicing activity in extracts depleted of yeast U6, associate with yeast splicing proteins, and interact with yeast U4. To test this possibility, human U6 RNA, synthesized in vitro using SP6 RNA polymerase (Pikielny et al. 1989|, was added to the oligonucleotide-treated extract, and the restoration of splicing activity was monitored by the addition of actin pre-mRNA (Fig. 9A, lanes 6-8). Despite the strong conservation of sequence, the synthetic human U6 RNA was unable to restore splicing of actin pre-mRNA. One explanation for this result is that the human U6 RNA is assembled less efficiently into snRNP particles and is degraded in yeast extracts, either because it is intrinsically unstable or because unassembled RNA is more accessible to nucleases. This, however, was not the case; ${ }^{32} \mathrm{P}$-labeled human U6 RNA was completely stable when it was incubated in yeast extracts (data not shown). To test whether the strong conservation of the U4/U6 interaction domain of U6 $(80 \%$ of identity) was sufficient to allow the formation of a hybrid U4/U6 snRNP (even if inactive), we performed immunoprecipitation experiments using anti$\mathrm{m}_{3} \mathrm{G}$ and anti-PRP4 antibodies. The results shown in Figure 9B (lanes 10-15) clearly established that human SP6U6 RNA does not interact with the endogenous yeast $\mathrm{U} 4$ and is unable to form a hybrid snRNP in vitro consisting of human U6 snRNA and yeast proteins.

\section{Discussion}

A requirement for the U6 snRNP in the splicing reaction has been demonstrated in mammalian cell extracts by site-directed cleavage of the U6 RNA with RNase H: HeLa cell extracts, in which portions of U6 snRNA have been selectively degraded, have a decreased efficiency of pre-mRNA splicing in vitro (Black and Steitz 1986). Recently, it has been demonstrated that the yeast U6 gene is essential in vivo (Brow and Guthrie 1988); however, the function(s) that the U6 snRNP plays in the splicing process is still unknown. Because its high degree of sequence conservation implies a fundamental role(s) in splicing, the experiments described here were undertaken as a first step toward understanding what this role(s) may be.

\section{Accessible sequences in the U6 snRNP}

We have shown that a number of oligonucleotides complementary to the yeast U6 RNA were able to direct RNase $\mathrm{H}$ cleavage of the U6 RNA, but only in one case was the cleavage efficient and complete. This oligonucleotide was complementary to 27 nucleotides of the central domain region, which is supposed to be, at least in part, single-stranded in mammals and in yeast (Black and Steitz 1986; Brow and Guthrie 1988) and which contains very highly conserved sequences. When ATP was absent during the RNase $\mathrm{H}$ degradation, the central domain of U6 was not accessible for cleavage by the enzyme. It became available when ATP was present, suggesting that this part of U6 has an important role. The 


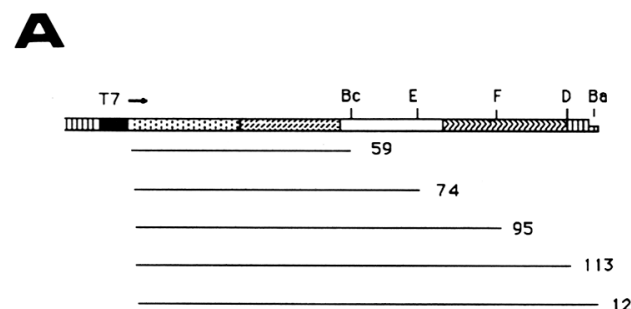

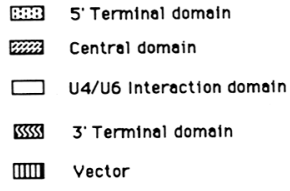

121

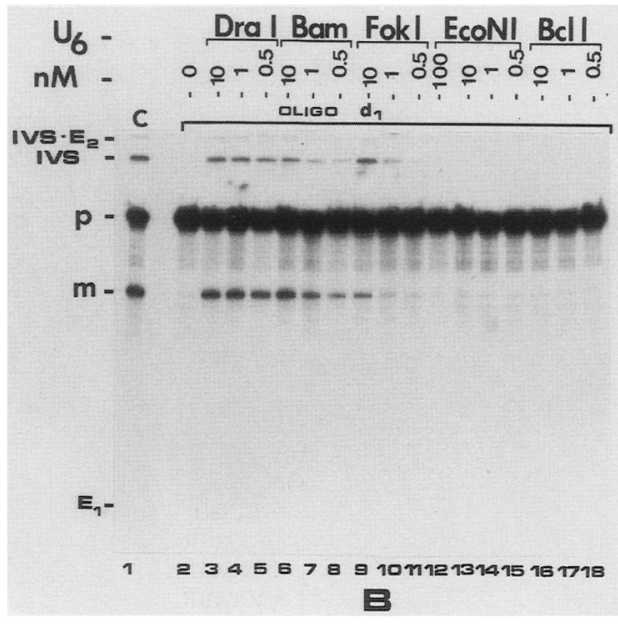

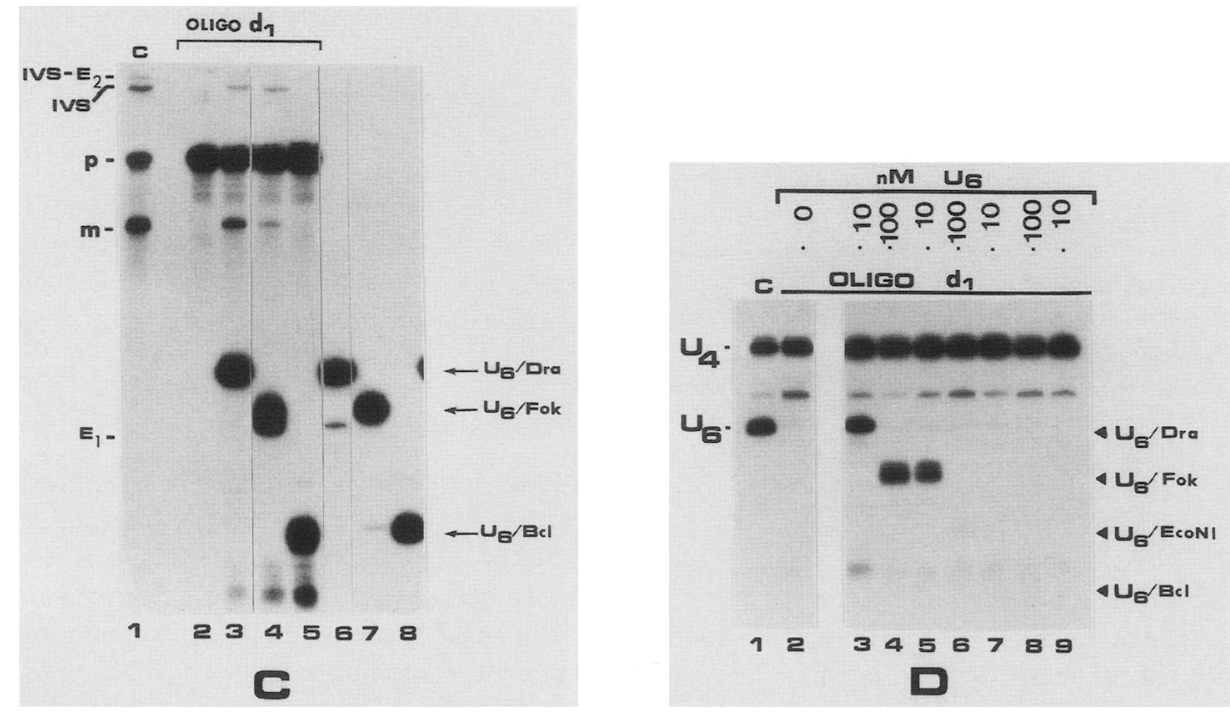

Figure 7. Identification of $\mathrm{U} 6$ sequences required for pre-mRNA splicing in vitro. $(A)$ The positions of the restriction sites in the U6 gene cloned under the T7 promoter [(Bc)BclI; (E) EcoNI; (F) FokI; (D) DraI; (Ba) BamHI] and the sizes of the corresponding RNA transcripts are shown in the schematic drawing. $(B)$ Splicing reconstitution by truncated RNAs. Conditions for reconstitution are described in Methods. $(C)$ Stability of the shorter U6 RNAs. Reconstitution reactions were carried out in the presence of ${ }^{32} \mathrm{P}$-labeled T7U6 transcripts. RNAs were analyzed on $10 \%$ acrylamide $-8 \mathrm{~m}$ urea gel. Lanes $6-8$ show the U6 transcripts of various length not incubated in the yeast extract. The BamHI and the EcoNI U6 truncated transcripts are not shown but gave the same results. The major reaction products and intermediates are labeled as follows: (IVS $=\mathrm{E}_{2}$ ) Intron-exon 2 ; (IVS) the excised intron; (p) precursor RNA $_{i}(\mathrm{~m})$ the spliced message $\left(\mathrm{E}_{1}\right)$ the excised exon $1 .(D)$ Immunoprecipitation of reconstituted U6 snRNPs was carried out with anti- $m_{3} \mathrm{G}$ antibodies using the same conditions described in Fig. 5A. Lane $1|C|$ is the control extract. The bands migrating between $\mathrm{U} 4$ and $\mathrm{U} 6$ and under $\mathrm{U} 6$ are degradation products of $\mathrm{U} 4$ and $\mathrm{U} 6$, respectively.

particularly strong conversation of the $3^{\prime}$ half of the central domain indicates that this region may be more evolutionary constrained by its participation in multiple interactions in the splicing process (Guthrie and Patterson 1988).

The cleavage patterns we obtained with the other oligonucleotides suggest additional U6 RNA structural features. First, in yeast, as in mammals, the 5'-terminal domain of U6 is only partially sensitive to RNase H degradation, even at the highest concentration used in this study. This is consistent with the hypothesis of others (Black and Steitz 1986) that this region constitutes a recognition site for a U6-binding protein. Other explana- tions are that the sequence in this region may not be available for hybridization to the oligonucleotide because of its proposed hairpin structure (Brow and Guthrie 1988). Also, binding of oligonucleotide b may not occur efficiently because of its self-complementarity. It is interesting to note that the shorter form of U6 produced by this cleavage seems to be rather unstable. Second, the U4/U6 interaction domain of U6 appears to be a region particularly resistant to RNase $\mathrm{H}$ targeting, even in the presence of ATP. This contradicts the notion that portions of this region are sensitive to RNase $\mathrm{H}$ cleavage only in the presence of ATP (Black and Steitz 1986). In light of the recent suggestion that 

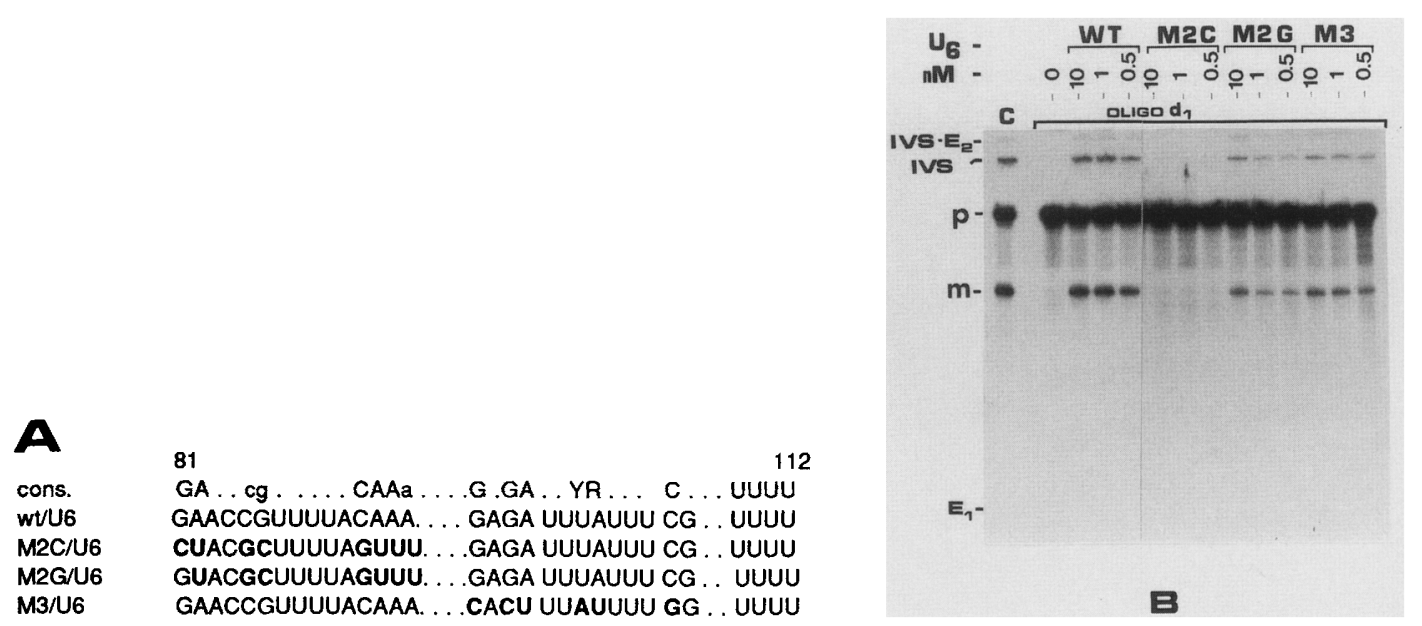

Figure 8. Mutational analysis of the $3^{\prime}$-terminal domain of U6 snRNA. (A) The sequence of the $3^{\prime}$-terminal domain of yeast U6 snRNA is shown (wt/U6). (cons) Consensus line; uppercase letters are invariant residues; $Y$ and $R$ indicate an invariant pyrimidine and purine, respectively. Residues identical among all the species except one are indicated by lowercase letters; two or more differences are indicated by dots (Guthrie and Patterson 1988). The U6 point mutations used in this study are indicated in boldface type. The names of the mutants are indicated at left. $(B)$ Splicing reconstitution of the different U6 RNA mutants indicated in $(A)$. Conditions for reconstitution are described in Materials and methods. The major reaction products and intermediates are labeled as follows: (IVS- $\mathrm{E}_{2}$ ) Intron-exon 2; (IVS) the excised intron; ( $\mathrm{p}$ ) precursor RNA; $(\mathrm{m})$ the spliced message; $\left(\mathrm{E}_{1}\right)$ the excised exon 1.

U4 and U6 undergo cyclic dissociation during the course of the splicing reaction (Cheng and Abelson 1987; Lamond et al. 1988), we propose that this portion of U6, once the complex with $\mathrm{U} 4$ is disrupted, may be engaged in additional interactions (McPheeters et al. 1989). Finally, structures proposed for the $3^{\prime}$-terminal domain of mammalian U6 cannot be formed in yeast (Brow and Guthrie 1988). Nevertheless, this unstructured region also is quite resistant to the targeted cleavage caused by oligonucleotide $\mathrm{f}$. Because extracts containing the shortened form of U6, lacking nearly all of the $3^{\prime}$-terminal domain, still splice pre-mRNA we conclude that nucleotides 82-112 are not absolutely required for splicing in vitro. However, our results suggest that they may be important for efficient splicing.

\section{In vitro-reconstituted U6 snRNP is identical to the endogenous U6 snRNP}

By synthesizing U6 RNA in vitro with T7 RNA polymerase and combining it with yeast extracts, we have demonstrated that the synthetic U6 RNA is fully functional in reconstituting $50-100 \%$ of splicing activity in extracts depleted of their endogenous U6 snRNA. After directing RNase $\mathrm{H}$ cleavage, the oligonucleotides are also destroyed, presumably by an endogenous deoxyribonuclease (DNase) activity. This important finding allows reconstitution without first incubating oligonucleotide-treated extracts with exogenous DNase I to remove oligonucleotides.

We examined the newly formed snRNP further and found that it is similar, if not identical, to the endogenous U6 snRNP present in yeast splicing extracts. Cheng and Abelson (1987) have observed that in the crude extract the endogenous U6 snRNP exists in sev- eral complexes, all of which have been identified using synthetic U6 RNA molecule. Moreover, we used immunoprecipitation experiments to demonstrate that the reconstituted U6 snRNP is structurally similar to the authentic U6 snRNP. By using anti- $\mathrm{m}_{3} \mathrm{G}$ antibodies, we have shown that the intermolecular base-pairing between the endogenous U4 RNA and the synthetic U6 RNA occurs efficiently. In addition, anti-PRP4 antibodies immunoprecipitate only $\mathrm{U} 4$ in an extract in which endogenous U6 RNA has been digested, but they coprecipitate both U4 and the T7U6 after its addition to the extract. This reinforces the notion that the reconstituted particles are physically similar to their endogenous counterparts.

Several forms of the spliceosome have been detected by electrophoresis of splicing mixtures in nondenaturing polyacrylamide gels in both mammalian and yeast systems (Konarska and Sharp 1986; Pikielny et al. 1986; Cheng and Abelson 1987). We found that cleavage of the endogenous U6 snRNA results in the accumulation of the earliest complex detectable in spliceosome assembly (complex B). Addition of the T7U6 transcript to the oligonucleotide-treated extract restores the ability of the extract to form the later complexes.

\section{Functions of the 3'-terminal domain}

To define what parts of the U6 snRNA are required in the splicing process, we compared reconstitution activities of several U6 RNA transcripts truncated at their 3' ends. This analysis revealed that U6 RNA molecules lacking 54 and 39 nucleotides are unable to restore splicing activity in vitro, to interact with the endogenous $U 4$, and to participate in spliceosome formation. In contrast, deletion of the $183^{\prime}$-terminal nucleotides of 

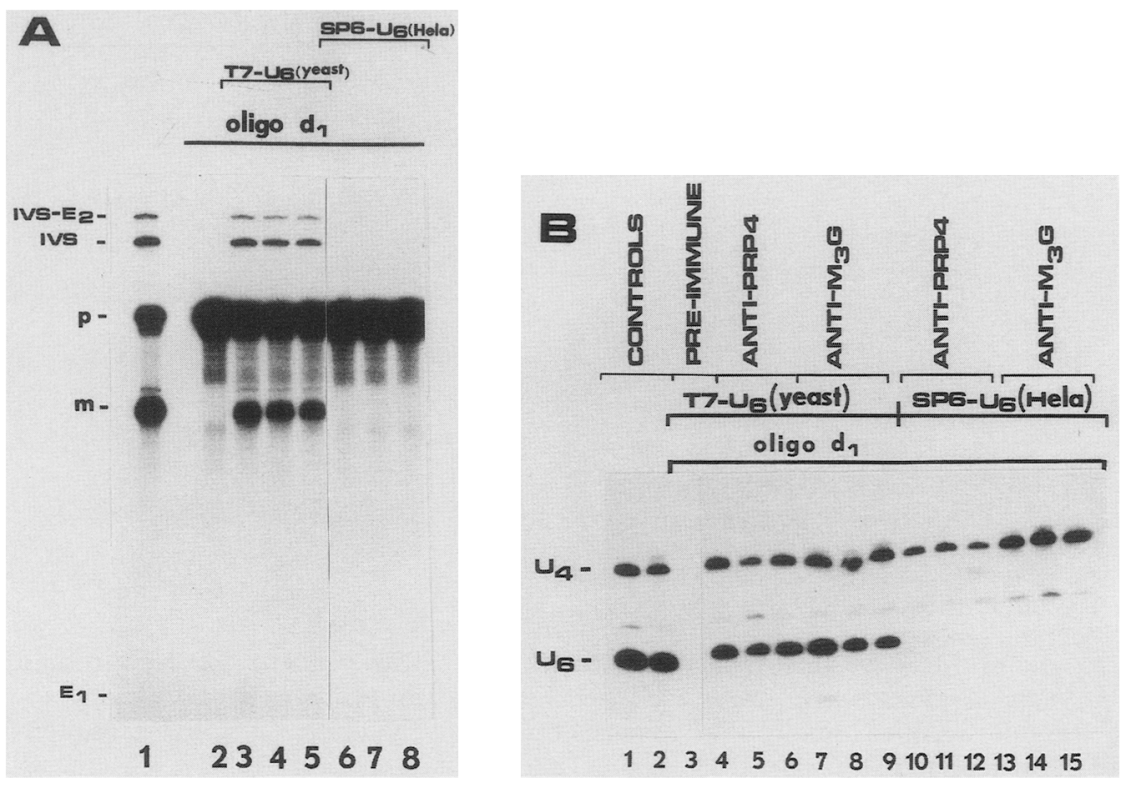

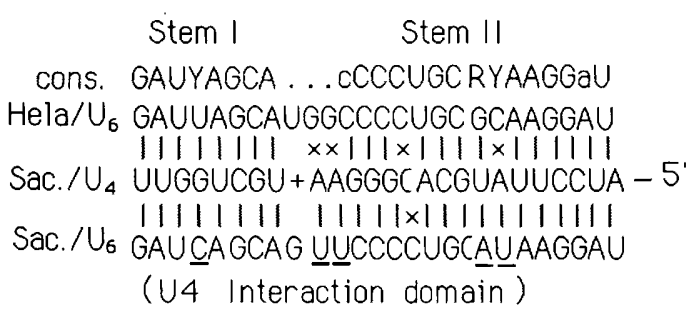

lanes show the immunoprecipitation of control extracts with anti-PRP4 (lane 1) and anti-m the U4/U6 interaction domain of HeLa and yeast U6. Stems I and II refer to intermolecular helices formed with U4. (cons) Consensus line; uppercase letters are invariant residues; $\mathrm{Y}$ and $\mathrm{R}$ indicate an invariant pyrimidine or purine, respectively. Residues identical among all the species except one are indicated by a lowercase letter; two or more differences are indicated by dots (Guthrie and Patterson 1988). Base-pairing is signified with a dashed line; unpaired nucleotides are signified with a cross. Variable nucleotides between HeLa and yeast U6 are underlined. Sac/U4 and Sac/U6 are S. cerevisiae U4 and U6, respectively.

U6 RNA results in a decrease of these activities and also in a diminution in the level of spliced message and accumulation of intron lariat. This suggests that nucleotides from position 95 to 112 are important for efficient assembly and/or may also have a role of holding the excised $5^{\prime}$ exon in the splicing complex after cleavage at the $5^{\prime}$ splice site (Steitz et al. 1988). Nevertheless, these 18 terminal nucleotides are not absolutely required (Table 1). These results are confirmed by our oligonucleotide-directed RNase $\mathrm{H}$ cleavage experiments. The fact that the shortened form of the endogenous U6 snRNA, lacking $\sim 31$ nucleotides of the 3 '-terminal domain (approximately at nucleotides $82-112$ ), is capable of mediating splicing of actin pre-mRNA with the same effects in the level of mRNA and intron lariat makes the preceding results stronger. The 3 '-terminal domain is highly divergent in sequence, although almost constant in length (Brow and Guthrie 1988). Our data suggest that the phylogenetic conservation of the size of this region of U6 may have biological importance. Interestingly, fidelity and/or efficiency of restoration of splicing are not only perturbed by shorter RNA species (95 nucleotides) but also longer species (121 nucleotides) than the reference U6 molecule (113 nucleotides).

Mutational analysis of the 3 '-terminal domain of U6 snRNA confirms that conserved nucleotides of this region contribute to the efficiency of reconstitution of splicing activity but are not absolutely required. Taken together, these results argue for a minor importance of the sequence of the 3 '-terminal domain of U6 and suggest that its length may have a role.

Substitution of the invariant G81 with C in synthetic U6 RNA abolishes its ability to restore splicing activity. Although base-pairing with U4 in this U6 RNA variant is still very efficient, its ability to participate in spliceosome formation is lost. Thus, the U4/U6 snRNP forms correctly, but mature spliceosomes do not assemble (Table 1).

\section{The failure of human $U 6$ to function in yeast extracts}

In striking contrast to other yeast spliceosomal RNAs, U6 is very similar in size, sequence, and structure to its mammalian homolog. Indeed, there is $60 \%$ identity over 
Table 1. U6 RNA sequence requirements for splicing and reconstitution

\begin{tabular}{|c|c|c|c|c|c|}
\hline \multirow{2}{*}{$\begin{array}{l}\text { U6 RNa runoff } \\
\text { and mutants }\end{array}$} & \multirow{2}{*}{$\begin{array}{l}\text { Length } \\
\text { (nucleotides) }\end{array}$} & \multicolumn{2}{|c|}{ Splicing efficiency $|\%\rangle$} & \multirow{2}{*}{$\begin{array}{l}\text { Interaction } \\
\text { with U4 }\end{array}$} & \multirow{2}{*}{$\begin{array}{l}\text { Spliceosome } \\
\text { assembly }\end{array}$} \\
\hline & & mRNA & IVS & & \\
\hline DraI & 113 & 80 & 80 & yes & yes \\
\hline BamHI & 121 & 62 & 58 & $\mathrm{NT}^{\mathrm{a}}$ & $\mathrm{NT}^{\mathrm{a}}$ \\
\hline FokI & 95 & 34 & $100-130$ & yes & yes \\
\hline EcoNI & 74 & 0 & 0 & no & no \\
\hline Bcll & 59 & 0 & 0 & no & no \\
\hline $\mathrm{M} 2 \mathrm{C} / \mathrm{U} 6$ & 113 & 0 & 0 & yes & no \\
\hline M2G/U6 & 113 & 30 & 30 & yes & yes \\
\hline M3/U6 & 113 & 45 & 45 & yes & yes \\
\hline
\end{tabular}

U6 RNAs of various lengths and U6 RNA mutants of the 3 '-terminal domain listed were tested for their ability to reconstitute splicing activity in vitro. The interaction with the endogenous $U 4$ was analyzed by immunoprecipitation with anti- $m_{3} G$ antibodies. Spliceosome assembly was examined on nondenaturing polyacrylamide gel (Cheng and Abelson 1987). Splicing efficiency was quantified by Cerenkov emission of isolated bands corresponding to the spliced message and the excised intron, respectively, of the $10 \mathrm{nM}$ T7-U6 reconstitution. The value of the control extract was taken as $100 \%$.

a(NT) Not tested.

the full length of yeast and mammalian U6, increasing to $>80 \%$ identity in the middle third of the RNAs. Microinjection experiments in Xenopus laevis oocytes have shown that snRNP-like particles can be assembled with snRNAs from a wide variety of organisms, even from S. cerevisiae (Riedel et al. 1987; Tollervey and Mattaj 1987), whose snRNAs are the most divergent in size and sequence from those of higher eukaryotes (Kretzner et al. 1987). In contrast, our data demonstrate that the human SP6/U6 RNA does not restore splicing activity nor does it interact with endogenous yeast $U 4$ in yeast extracts and, as a result, it is not incorporated into the yeast spliceosome (data not shown). Why is the human U6 transcript inactive in yeast extract? One explanation is that the $5^{\prime}$-terminal region is different in length and sequence between yeast and mammals. Alternatively, in mammalian U6, the central domain is predicted to base-pair with a region in the 3 '-terminal domain to form a stem that cannot be formed in yeast U6 (Brow and Guthrie 1988). These differences may prevent the human U6 RNA from assembling correctly in yeast extracts. Why does the human U6 transcript not interact with the endogenous yeast $U 4$ ? To understand the reason for the lack of base-pairing, we analyzed the U4/U6 interaction domain of both human and yeast U6 RNAs. It has been proposed (Brow and Guthrie 1988) that two main regions of $\mathrm{U} 4$ and $\mathrm{U} 6$ are base-paired and are separated by a U4 stem-loop structure. Within stem I, HeLa and yeast U6 RNAs differ in sequence at one position (Fig. 9C, underlined nucleotides), but the difference does not affect the base-pairing with the yeast $U 4$ snRNA. Within stem II, they differ at four positions, three of which could interfere with the base-pairing. Actually, the interaction of human U6 with human $\mathrm{U} 4$ is not better; three nucleotides are still unpaired. Perhaps, the sequence complementarity is not the only element important for the association between $\mathrm{U} 4$ and $\mathrm{U} 6$, the contribution of species-specific RNA-binding proteins, which stabilize the base-pairing, may be important. The last hypothesis may be especially true in mammals, as it was impossible to reassociate the deproteinized snRNAs
U4 and U6 once the complex had been temperature-dissociated (Hashimoto and Steitz 1984; Rinke et al. 1985).

\section{Conclusions}

We assembled synthetic U6 RNA in vitro into a functional snRNP that is physically identical to the endogenous U6 snRNP, is immunoprecipitated by the same antibodies, and participates in spliceosome formation. There are many examples of reconstitution of snRNPs using $X$. laevis egg extracts or HeLa cell S100 extracts (Hamm et al. 1987, 1988; Patton et al. 1987; Patton and Pederson 1988; Kleinschmidt et al. 1989; Pikielny et al. 1989) and examples of functional assembly of human snRNA with amphibian or HeLa proteins (Krainer 1988; Pan and Prives 1988). This work and that of McPheeters et al. (1989) are the first examples of synthetic U-RNAs that are able to restore splicing in vitro. An important outcome of this experimental approach is that it constitutes a powerful tool for the identification of the sequences in snRNAs that are required for particle formation, for pre-mRNA splicing, and for spliceosome assembly. This is especially important in the case of U6, as it has been speculated that the extreme conservation of size, sequence, and structure reflects a fundamental role, perhaps one at the heart of trans-mediated catalysis of splicing (Guthrie and Patterson 1988).

\section{Materials and methods}

Subcloning of the yeast U6 gene under the T7 promoter and construction of mutants

Because of the paucity of convenient restriction sites of the U6 snRNA gene (Brow and Guthrie 1988), the linkage to the bacteriophage T7 promoter was done by self-assembly of six synthetic oligodeoxynucleotides (Reyes and Abelson 1987), as shown in Figure 1A. The six synthetic oligomers were purified by electrophoresis on denaturing $15 \%$ polyacrylamide gels and phosphorylated in a separate reaction mixture with T4 polynucleotide kinase. Stoichiometric amounts of each oligomer were combined and annealed by evaporation to dryness. This construct was then cloned into the EcoRI/BamHI sites of 
M13mp18. The identity of the insert was proved by the dideoxy sequencing method (Sanger et al. 1977) with Scquenase (U.S. Biochemicals). An extra $G$ was added at the $5^{\prime}$ end of the U6 gene to improve the T7 promoter strength (Milligan et al. 1987). Transcription by $\mathrm{T} 7$ polymerase starts at the extra $\mathrm{G}$ added at the 5' end of the U6 gene and terminates at the DraI site at the $3^{\prime}$ end to give a 113-nucleotide RNA molecule with a sequence identical to an unmodified yeast U6 RNA. The T7 promoter/U6 gene construct was subcloned in the EcoRI/PstI site of the vector pUC18 to give a recombinant plasmid designed pT7U6 to obtain larger quantities of DNA.

U6 RNA variants of the 3'-terminal domain were constructed by total gene synthesis. Both oligonucleotides e and $f$ (Fig. 1A) were changed to obtain the mutations listed in Figure 8A. In all cases, the sequence of the mutant gene insert was determined by the dideoxy sequencing method, as above.

\section{T7 RNA synthesis}

For the unlabeled RNA synthesis, $10 \mu \mathrm{g}$ of pT7U6 DNA was cut with the appropriate restriction endonucleases and incubated in a volume of $100 \mu \mathrm{l}$ containing $40 \mathrm{mM}$ Tris $-\mathrm{HCl} / \mathrm{pH}$ 8.0 ), $106 \mathrm{mM} \mathrm{MgCl}, 2 \mathrm{~mm}$ spermidine, $10 \mathrm{~mm}$ DTT, $2.5 \mathrm{~mm}$ ATP, UTP, GTP, and CTP, 300 units of T7 polymerase (or SP6 polymerase, in the case of the human U6), and 160 units of RNasin, at $37^{\circ} \mathrm{C}$ for $2 \mathrm{hr}$. Transcription reaction was terminated by adding formamide loading buffer. RNAs were visualized by UV shadowing and eluted from the gel in $0.5 \mathrm{M}$ sodium acetate (pH 5.0), $1.0 \mathrm{mM}$ EDTA (pH 8.0), and $2.5 \%$ phenol/chloroform at $4^{\circ} \mathrm{C}$ for $13-15 \mathrm{hr}$ and then phenol/chloroform extracted and ethanol precipitated. U6 RNA $(5-10 \mu \mathrm{g})$ was synthesized by this method, as determined by absorption at $260 \mathrm{~nm}$. ${ }^{32} \mathrm{P}$-labeled transcripts were synthesized as described above, except that the reaction $(20.0 \mu l)$ contained $1 \mathrm{mM}$ ATP, GTP, and CTP and $0.2 \mathrm{mM}$ UTP, $6 \mathrm{mM} \mathrm{MgCl}$, and $50 \mu \mathrm{Ci}$ of $\left[\alpha^{32} \mathrm{P}\right] \mathrm{UTP}$ (3000 $\mathrm{Ci} / \mathrm{mmole})$.

\section{Oligonucleotide-directed RNase $H$ cleavage and in vitro functional assay}

For the cleavage of the endogenous U6 snRNA, splicing extracts were incubated for $30 \mathrm{~min}$ at $30^{\circ} \mathrm{C}$ with the appropriate oligonucleotide as indicated at the top of Figure $2 \mathrm{~A}$ and B. Note that oligonucleotide $\mathrm{b}$ contains 18 nucleotides of $\mathrm{T} 7$ promoter (at the $5^{\prime}$ end) and oligonucleotide $f$ contains 8 nucleotides of the restriction sites (at the $3^{\prime}$ end) that are not complementary to the U6 snRNA. Typical cleavage reactions were performed for $2 \mu \mathrm{l}$ of splicing extract in $4-\mu \mathrm{l}$ reaction mixtures containing $2.5 \mathrm{mM} \mathrm{MgCl}_{2}, 3 \%$ PEG-8000, $60 \mathrm{~mm}$ potassium phosphate $(\mathrm{pH}$ 7.0 ), $2 \mathrm{~mm}$ spermidine, and 0.3 or $3.0 \mu \mathrm{M}$ oligonucleotides in the presence or absence of $2 \mathrm{mM}$ ATP. No exogenous RNase $\mathrm{H}$ was added because yeast splicing extract contains endogenous $\mathrm{RNase} \mathrm{H}$ activity. For in vitro functional assay, after treatment of the extract with $0.3 \mu \mathrm{M}$ oligonucleotide $\mathrm{dl}$ in the presence of $2 \mathrm{~mm} \mathrm{ATP}, 0.5 \mu \mathrm{l}$ of in vitro-synthesized U6 RNA (resuspended in water) was added and allowed to assemble for 5-10 $\mathrm{min}$ at $23^{\circ} \mathrm{C}$. Then, 1 fmole of the ${ }^{32} \mathrm{P}$-labeled actin precursor was added in a volume of $0.5 \mu \mathrm{l}$ of the same buffer as above, except that the concentration of the reagents was $2 \times$. The samples were incubated for $30 \mathrm{~min}$ at $23^{\circ} \mathrm{C}$. The reactions were terminated as described by Lin et al. (1985).

\section{Preparation of the splicing extract and substrates}

Yeast whole-cell extracts and actin pre-mRNA substrate were prepared according to Lin et al. (1985). Unlabeled actin transcripts were synthesized as described above.

\section{Stability of oligonucleotides in yeast extract}

Oligonuclcotide d (30 pmole) was $3^{\prime}$-terminal-labeled with $5^{\prime}$ [32P]pCp and T4 RNA ligase, as described by Ruby et al. (1989). This gives the penultimate 3 ' phosphate a radioactive label. Labeled oligonucleotides were gel-purified and incubated into whole-cell yeast extract for $30 \mathrm{~min}$ at $30^{\circ} \mathrm{C}$, as described for the in vitro functional assay. After phenol extraction and ethanol precipitation, they were analyzed on a denaturing $15 \%$ acrylamide gel.

\section{Immunoprecipitation}

As described by Cheng and Abelson (1986), 1.5-2.5 $\mu \mathrm{l}$ serum, $2.5 \mathrm{mg}$ of protein A-Sepharose (Pharmacia), $0.5 \mathrm{ml}$ of NET-2 buffer [50 mM Tris-HCl $(\mathrm{pH} 7.5), 0.05 \%$ Nonidet $\mathrm{P}-40$, and 150 $\mathrm{mm} \mathrm{NaCl}$ ] were mixed for $1 \mathrm{hr}$ at $4^{\circ} \mathrm{C}$, and the beads washed three times with $0.5 \mathrm{ml}$ of the same buffer. After the reconstitution, the mixtures were immunoprecipitated by adding the antibody-bound protein A-Sepharose to the in vitro assembly mix in a total volume of $0.5 \mathrm{ml}$, and the mixture was rolled for $2 \mathrm{hr}$ at $4^{\circ} \mathrm{C}$. The beads were then washed three times with $1 \mathrm{ml}$ of NET buffer, and the precipitated RNAs released by digestion with proteinase $\mathrm{K}$ for $15 \mathrm{~min}$ at $37^{\circ} \mathrm{C}$. RNAs were extracted with phenol/chloroform, precipitated, fractionated on a $5 \%$ or $8 \%$ acrylamide $-8 \mathrm{M}$ urea gel, and electroblotted as described below.

\section{In vitro complex formation}

Nondenaturing polyacrylamide gel electrophoresis was performed according to Cheng and Abelson (1987). Electrophoresis for splicing complex analysis was at $300 \mathrm{~V}$ for $30 \mathrm{~min}$, followed by electrophoresis at $230 \mathrm{~V}$ for $5 \mathrm{hr}$ at $4^{\circ} \mathrm{C}$. For RNPs, analysis electrophoresis was at $300 \mathrm{~V}$ for $1 \mathrm{hr}$ at $4^{\circ} \mathrm{C}$ in a buffer containing $20 \mathrm{~mm}$ Tris- $\mathrm{HCl}(\mathrm{pH} 8.0)$ and $1 \mathrm{~mm}$ EDTA.

\section{Northern blot analysis}

RNAs were electroblotted onto GeneScreen membranes (NEN) at $4^{\circ} \mathrm{C}$ in $25 \mathrm{~mm}$ sodium phosphate buffer (pH 6.5), for $20 \mathrm{hr}$ at $25 \mathrm{~V}$ for denaturing gels and for $2-4 \mathrm{hr}$ at $40 \mathrm{~V}$ for nondenaturing gels. The blots were UV-irradiated for $10 \mathrm{~min}$, as described by Cheng and Abelson (1987). Prehybridization and hybridization were carried out at $42^{\circ} \mathrm{C}$ in a solution containing $50 \%$ formamide, $25 \mathrm{~mm}$ sodium phosphate $(\mathrm{pH} 6.5), 6 \times$ SSC, $5 \times$ Denhardt's solution, $0.5 \%$ SDS, and $0.1 \mathrm{mg} / \mathrm{ml}$ heat-inactive calf thymus DNA. After hybridization, membranes were washed twice for $5 \mathrm{~min}$ in $2 \times \mathrm{SSC}$ and $0.5 \%$ SDS at room temperature, twice for $5 \mathrm{~min}$ in $2 \times$ SSC and $0.1 \%$ SDS at room temperature and, finally, once for $30 \mathrm{~min}$ in $2 \times \mathrm{SSC}$ and $0.1 \%$ SDS at $50^{\circ} \mathrm{C}$. The U6 probe was a mixture of oligonucleotides $b$, $\mathrm{d}$, and $\mathrm{f}$, listed in Figure 1A, whereas the U4 probe was a mixture of oligonucleotides complementary to the full-length U4 snRNA (Siliciano et al. 1987). Oligonucleotides were ${ }^{32} \mathrm{P}-1 \mathrm{a}-$ beled at the 5 ' end by $\mathrm{T} 4$ polynucleotide kinase and included in the hybridization buffer at $5 \times 10^{6}$ to $10 \times 10^{6} \mathrm{cpm}$ in each 25 $\mathrm{ml}$ of the hybridization solution.

\section{Acknowledgments}

We thank J. Banroques and R. Lührmann for gifts of anti-PRP4 and anti- $\mathrm{m}_{3} \mathrm{G}$ antibodies. We are grateful to $\mathrm{D}$. Brow and $\mathrm{C}$. Guthrie for generously providing the U6 gene sequence before publication and to C. Pikielny and M. Green for the HeLa SP6/U6 gene construct. We also thank K. Tanner, L. Krinke, S. 
Ruby, and J. Banroques for critical comments on the manuscript and helpful discussion. We thank S. Horvath for synthesizing oligonucleotides and $\mathrm{C}$. Blagg for typing the manuscript. P.F. was supported by a grant from the Foundation Stiftelsen Blanceflor Boncompagni-Ludovisi Född Bildt. D.S.M. was supported by U.S. Public Health Science grant GM-12544. This work was supported by National Institutes of Health grant GM-32637.

\section{References}

Banroques, J. and J. Abelson. 1989. PRP4: A protein of the yeast U4/U6 small nuclear ribonucleoprotein particle. Mol. Cell Biol. 9: 3698-3707.

Berget, S.M. and B.L. Robberson. 1986. U1, U2 and U4/U6 small nuclear ribonucleoproteins are required for in vitro splicing but not polyadenylation. Cell 46: 691-696.

Black, D.L., B. Chabot, and J.A. Steitz. 1985. U2 as well as U1 small nuclear ribonucleoproteins are involved in pre-mRNA splicing. Cell 42: 737-750.

Black, D.L. and J. A. Steitz. 1986. Pre-mRNA splicing in vitro requires intact U4/U6 small nuclear ribonucleoprotein. Cell 46: $697-704$.

Bringmann, P., R. Renter, J. Rinke, B. Appel, R. Bald, and R. Lührmann. 1983. 5' Terminal caps of snRNAs are accessible for reaction with 2,2,7-trimethylguanosine specific antibody in intact snRNPs. I. Biol. Chem. 258: 2745-2747.

Bringmann, P., B. Appel, J. Rinke, R. Reuter, H. Theissen, and R. Lührmann. 1984. Evidence for the existence of snRNAs $\mathrm{U} 4$ and $\mathrm{U} 6$ in a single ribonucleoprotein complex and for their association by inter-molecular base pairing. $E M B O \mathrm{I}$. 3: $1357-1363$.

Brody, E. and J. Abelson. 1985. The 'spliceosome': A yeast premessenger RNA associates with a $40 \mathrm{~S}$ complex in a splicing-dependent reaction. Science 228: 963-967.

Brow, D.A., and C. Guthrie. 1988. Spliceosomal RNA U6 is remarkably conserved from yeast to mammals. Nature 334: $213-218$.

1989. Splicing a spliceosomal RNA. Nature 337: 14-15.

Chabot, B., D.L. Black, D.M. De Master, and J.A. Steitz. 1985. The 3' splice site of pre-messenger RNA is recognized by a small nuclear ribonucleoprotein. Science 230: 1344-1349.

Chabot, B. and J.A. Steitz. 1987. Multiple interactions between the splicing substrate and small ribonucleoproteins in spliceosomes. Mol. Cell Biol. 7: 281-293.

Cech, T.R. 1986. The generality of self-splicing RNA: Relationship to nuclear mRNA splicing. Cell 44: 207-210.

Cheng, S.-C. and J. Abelson. 1986. Fractionation and characterization of a yeast mRNA splicing extract. Proc. Natl. Acad. Sci. 83: 2397-2391.

- 1987. Spliceosome assembly in yeast. Genes Dev. 1: 1014-1027.

Das, G., D. Henning, and R. Reddy. 1987. Structure, organization, and transcription of Drosophila U6 small nuclear RNA genes. J. Biol. Chem. 262: 1187-1193.

Frendewey, D. and W. Keller. 1985. The stepwise assembly of a pre-mRNA splicing complex requires U-snRNPs and specific intron sequences. Cell 42: 355-367.

Gerke, V. and J.A. Steitz. 1986. A protein associated with small nuclear ribonucleoprotein particles recognizes the $3^{\prime}$ splice site of pre-messenger RNA. Cell 47: 973-984.

Grabowski, P.J., S.R. Seiler, and P.A. Sharp. 1985. A multicomponent complex is involved in the splicing of messenger RNA precursors. Cell 42: 345-353.

Green, M.R. 1986. Pre-mRNA splicing. Annu. Rev. Genet. 20: $671-708$.
Guthrie, C. and B. Patterson. 1988. Spliceosomal snRNAs. Annu. Rev. Genet. 22: 387-418.

Hamm, J., M, Kazmaier, and I.W. Mattaj. 1987. In vitro assembly of U1 snRNPs. EMBO I. 6: 3470-3485.

Hamm, J., V.L. Van Santen, R.A. Spritz, and I.W. Mattaj. 1988. Loop I of U1 small nuclear RNA is the only essential RNA sequence for binding of specific U1 small nuclear ribonucleoprotein particle proteins. Mol. Cell Biol. 8: 4787-4791.

Hashimoto, C. and J.A. Steitz. 1984. U4 and U6 RNAs coexist in a single small ribonucleoprotein particle. Nucleic Acids Res. 12: 3283-3293.

Kiss, T., G. Jakab, M. Antal, Z. Pálfi, H. Hegyi, M. Kis, and F. Solymosy. 1988. Plant small nuclear RNAs. V. U4 RNA is present in broad beanplants in the form of sequence variants and is base-paired with U6 RNA. Nucleic Acids Res. 16: $5407-5426$.

Kleinschmidt, A.M., J.R. Patton, and T. Pederson. 1989. U2 small nuclear RNP assembly in vitro. Nucleic Acids Res. 17: 4817-4828.

Konarska, M.M. and P.A. Sharp. 1986. Electrophoretic separation of complexes involved in the splicing of precursors to mRNAs. Cell 46: 845-855.

Krainer, A.R. and T. Maniatis. 1985. Multiple factors including the small nuclear ribonucleoproteins $\mathrm{U} 1$ and $\mathrm{U} 2$ are necessary for pre-mRNA splicing in vitro. Cell 42: 725-736.

Krainer, A.R. 1988. Pre-mRNA splicing by complementation with purified human U1, U2, U4/U6, and U5 snRNPs. $\mathrm{Nu}$ cleic Acids Res. 16: 9415-9429.

Krämer, A., W. Keller, B. Appel, and R. Lührmann. 1984. The 5' terminus of the RNA moiety of U1 small nuclear ribonucleoprotein particles is required for the splicing of messenger RNA precursor. Cell 38: 299-307.

Kretzner, L, B.C. Rymond, and M. Rosbash. 1987. S. cerevisiae U1 RNA is large and has limited primary sequence homology to metazoan Ul snRNA. Cell 50: 593-602.

Lamond, A.I., M.M. Konarska, P.J. Grabowski, and P.A. Sharp. 1988. Spliceosome assembly involves the binding and the release of U4 small nuclear ribonucleoprotein. Proc. Natl. Acad. Sci. 85: 411-415.

Lerner, M.R., J.A. Boyle, S.M. Mount, S.L. Wolin, and J.A. Steitz. 1980. Are snRNPs involved in splicing? Nature 283: 220-224.

Lin, R.J., A. J. Newman, S.-C. Cheng, and J. Abelson. 1985. Yeast mRNA splicing in vitro. I. Biol. Chem. 260: 1478014792.

Lührmann, R. 1988. snRNP proteins. In Structure and function of major and minor small nuclear ribonucleoprotein particles. (ed. M.L. Birnstiel), pp. 71-99. Springer-Verlag, Berlin, Heidelberg, New York, London, Paris, Tokyo.

Maniatis, T. and R. Reed. 1987. The role of small nuclear ribonucleoproteins in pre-mRNA splicing. Nature 325: 673-678.

Mattaj, I.W. 1988. UsnRNP assembly and transport. In Structure and function of major and minor small nuclear ribonucleoprotein particles. (ed. M.L. Birnstiel), pp. 100-112. Springer-Verlag, Berlin, Heidelberg, New York, London, Paris, Tokyo.

-1989. A binding consensus: RNA-protein interactions in splicing, snRNPs, and sex. Cell 57: 1-3.

McPheeters, D., P. Fabrizio, and J. Abelson. 1989. In vitro reconstitution of functional yeast U2 snRNPs. Genes Dev. 3: 2124-2136.

Milligan, J.F., D.R. Groebe, G.W. Witherall, and O.C. Uhlenbeck. 1987. Oligoribonucleotide synthesis using T7 RNA polymerase and synthetic DNA templates. Nucleic Acids Res. 15: 8783-8798.

Mottram, I., K.L. Perry, P.M. Lizardi, N. Agabian, and R.G. 
Nelson. 1989. Isolation and sequence of four small nuclear URNA genes of Trypanosoma brucei subsp. brucei: Identification of the U2, U4, and U6 RNA analogs. Mol. Cell Biol. 9: $1212-1223$.

Mount, S.M., I. Pettersson, M. Hinterberger, A. Karmas, and J.A. Steitz. 1983. The U1 small nuclear RNA-protein complex selectively binds a $5^{\prime}$ splice site in vitro. Cell 33: 509518.

Padgett, R.A., P.J. Grabowski, M.M. Konarska, S. Seiler, and P.A. Sharp. 1986. Splicing of messenger RNA precursors. Annu. Rev. Biochem. 55: 1119-1150.

Pan, Z.Q. and C. Prives. 1988. Assembly of functional U1 and U2 human-amphibian hybrid snRNPs in Xenopus laevis oocytes. Science 241: $1328-1330$.

Parker, R., P.G. Siliciano, and C. Guthrie. 1987. Recognition of the TACTAAC box during mRNA splicing in yeast involves base pairing to the U2-like snRNA. Cell 49: 229-239.

Parry, H.D., D. Scherly, and I.W. Mattaj. 1989. 'Snurpogenesis': The transcription and assembly of U snRNP components. Trends Biochem. Sci. 14: 15-19.

Patton, J.R., R.J. Patterson, and T. Pederson. 1987. Reconstitution of the U1 small nuclear ribonucleoprotein particle. Mol. Cell Biol. 7: 4030-4037.

Patton, J.R. and T. Pederson. 1988. The $M_{\mathrm{r}} 70,000$ protein of the U1 small nuclear ribonucleoprotein particle binds to the $5^{\prime}$ stem-loop of U1 RNA and interacts with Sm domain proteins. Proc. Natl. Acad. Sci. 85: 747-751.

Peebles, C.L. P.S. Perlman, D.L. Mecklenberg, M.L. Petrillo, J.H. Tabor, K.A. Jarrell, and H.-L. Cheng. 1986. A selfsplicing RNA excises an intron lariat. Cell 44: 213-223.

Pikielny, C.W., B.C. Rymond, and M. Rosbash. 1986. Electrophoresis of ribonucleoproteins reveals an ordered assembly pathway of yeast splicing complexes. Nature 324: 341-345.

Pikielny, C.W., A. Bindereif, and M. Green. 1989. In vitro reconstitution of snRNPs: A reconstitute U4/U6 snRNP participates in splicing complex formation. Genes Dev. 3: 479487.

Reddy, R. and H. Busch. 1988. Small nuclear RNAs: RNA sequence, structure, and modifications. In Structure and function of major and minor small nuclear ribonucleoprotein particles. (ed. M.L. Birnstiel), pp. 1-37. Springer-Verlag, Berlin, Heidelberg, New York, London, Paris, Tokyo.

Reyes, V.M. and J. Abelson. 1987. A synthetic substrate for tRNA splicing. Anal. Biochem. 166: 90-106.

Reidel, N., S. Wolin, and C. Guthrie. 1987. A subset of yeast snRNAs contains functional binding sites for the highly conserved Sm antigen. Science 235: 328-331.

Rinke, J., B. Appel, M. Digweed, and R. Lührmann. 1985. Localization of a base-paired interaction between small nuclear RNAs U4 and U6 in intact U4/U6 small ribonucleoprotein particles by psoralen cross-linking. I. Mol. Biol. 185: 721731.

Rogers, J. and R. Wall. 1980. A mechanism for RNA splicing. Proc. Natl. Acad. Sci. 77: 1877-1879.

Ruby, S.W. and J. Abelson. 1988. An early hierarchic role of U1 small nuclear ribonucleoprotein in spliceosome assembly. Science 242: 1028-1035.

Ruby, S.W., S.E. Goelz, Z. Hostomsky, and J. Abelson. 1989. Affinity chromatography with reversibly biotinylated RNAs. Methods Enzymol. (in press).

Sanger, F., S. Nicklen, and A.R. Coulson. 1977. DNA sequencing with chain terminating inhibitors. Proc. Natl. Acad. Sci. 74: 5463-5467.

Seraphin, B., K. Krezner, and M. Rosbash. 1988. A U1 snRNA: Pre-mRNA base pairing interaction is required early in yeast spliceosome assembly but does not uniquely define the $5^{\prime}$ cleavage site. $E M B O$ I. 7: 2533-2538.

Shapiro, M.B. and P. Senapathy. 1987. RNA splice junctions of different classes of eukaryotes: Sequences statistics and functional implication in gene expression. Nucleic Acids Res. 15: 7155-7174.

Sharp, P.A. 1987. Splicing of messenger RNA precursors. Science 235: 766-771.

Siliciano, P.G., D. A. Brow, H. Roiha, and C. Guthrie. 1987. An essential snRNA from $S$. cerevisiae has properties predicted for U4, including interaction with U6-like snRNA. Cell 50: $585-592$.

Siliciano, P.G. and C. Guthrie. 1988. 5' Splice-site selection in yeast: Genetic alteration in base-pairing with $\mathrm{Ul}$ reveal additional requirements. Genes Dev. 2: 1258-1267.

Steitz, J.A., D. Black, V. Gerke, K.A. Parker, A. Kramer, D. Frendewey, and W. Keller. 1988. Function of the abundant U-snRNPs. In Structure and function of major and minor small nuclear ribonucleoprotein particles (ed. M.L. Birnstiel), pp. 115-154. Springer-Verlag, Berlin, Heidelberg, New York, London, Paris, Tokyo.

Tani, T. and Y. Ohshima. 1989. The gene for the U6 small nuclear RNA in fission yeast has an intron. Nature 337: 8790.

Tazi, I., C. Alibert, I. Temsamani, I. Reveillaud, G. Cathala, C. Brunel, and P. Jeanteur. 1986. A protein that specifically recognizes the 3 ' splice site of mammalian pre-mRNA introns is associated with a small nuclear ribonucleoprotein. Cell 47: 755-766.

Tollervey, D. and I.W. Mattaj. 1987. Fungal small nuclear ribonucleoproteins share properties with plant and vertebrate U-snRNPs. EMBO J. 6: 469-476.

Van der Veen, R., A.C. Arnberg, G. Van der Horst, L. Bonen, H.F. Tabak, and L.A. Grivell. 1986. Excised group II introns in yeast mitochondria are lariats and can be formed by selfsplicing in vitro. Cell 44: 225-234.

Vijayraghavan, U. and J. Abelson. 1989. pre-mRNA splicing in yeast. In Nucleic acids and molecular biology (ed. F. Eckstein and D.M.J. Lilleyl, vol. 3, pp. 197-215, SpringerVerlag, Berlin, Heidelberg.

Zhuang, Y. and A.M. Weiner. 1986. A compensatory base change in Ul snRNA suppresses a $5^{\prime}$ splice site mutation. Cell 46: 827-835.

Zucker-Aprison, E., J.D. Thomas, and T. Blumenthal. 1988. C. elegans snRNAs: A model for U4/U6 base pairing. Nucleic Acids Res. 16: 7188. 


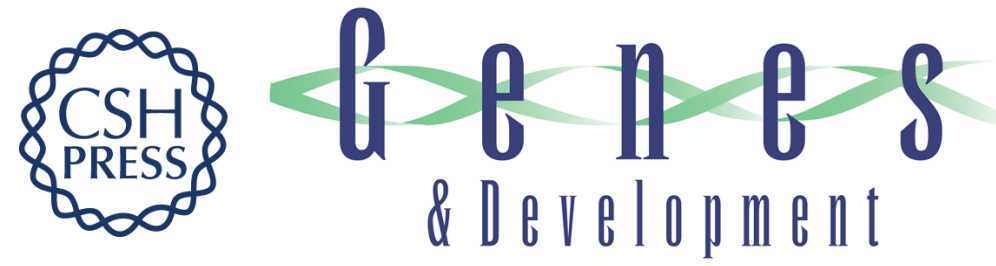

\section{In vitro assembly of yeast U6 snRNP: a functional assay.}

P Fabrizio, D S McPheeters and J Abelson

Genes Dev. 1989, 3:

Access the most recent version at doi:10.1101/gad.3.12b.2137

References This article cites 65 articles, 22 of which can be accessed free at: http://genesdev.cshlp.org/content/3/12b/2137.full.htmI\#ref-list-1

License

Email Alerting

Receive free email alerts when new articles cite this article - sign up in the box at the top Service right corner of the article or click here.

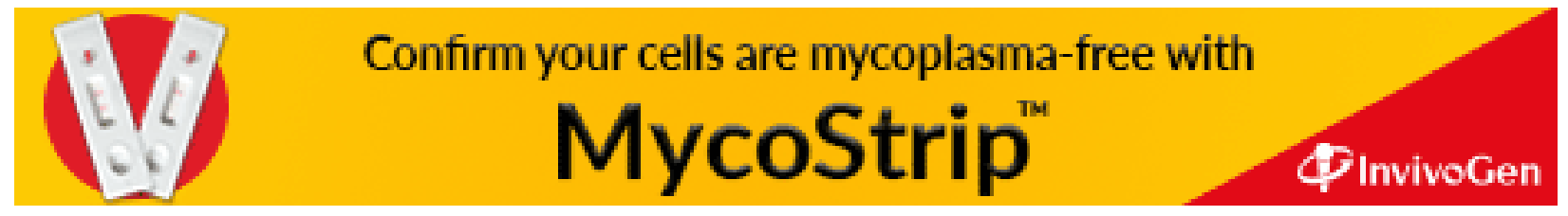

